\title{
Identification and Separation of Cannabis sativa, Embleia ribes, Myristica fragrans and Piper longum from Organic Extract on Silica Gel Surface with Anionic Micellar Solvent System: Application in Ayurvedic Medicine
}

\author{
A. Mohammad ${ }^{1, *}$, S. Sharma ${ }^{2}$, S.A. Bhawani ${ }^{3}$ and Ram B. Singh ${ }^{4}$ \\ ${ }^{1,2,3}$ Analytical Research Laboratory, Department of Applied Chemistry, Faculty of Engineering \& Technology, Aligarh \\ Muslim University, Aligarh-202002, India \\ ${ }^{4}$ Halberg Hospital and Research Institute, Civil Lines Moradabad-10, (U.P), India
}

\begin{abstract}
Cannabis sativa, Myristica fragrans, Piper longum and Embleia ribes are the active pharma ingredients of an ayurvedic herbal formulation Jatiphaldya, which is beneficial in many typical stomach related disorders.

The present study is aimed to develop a simple and reliable thin layer chromatographic (TLC) method using micellar solution of sodium dodecyl sulfate (SDS) as mobile phase for the identification of all the four herbal drugs with preliminary separation on silica gel 'G' TLC plate. The active components of drug were extracted in a mixture of ethanol and water (4:1), chromatographed on silica gel TLC plate using aqueous SDS (5\%) as mobile phase and the resolved spots for Cannabis sativa $\left(\mathrm{R}_{\mathrm{F}}-0.95\right)$, Myristica fragrans $\left(\mathrm{R}_{\mathrm{F}}-0.64\right)$, Piper longum $\left(\mathrm{R}_{\mathrm{F}}-0.41\right)$ and Embleia ribes $\left(\mathrm{R}_{\mathrm{F}}-0.26\right)$ were identified using vanillin-sulfuric acid (2\% solution of vanillin in 5\% methanolic sulfuric acid). In order to realize most favorable mobile phase system in combination with silica gel ' $G$ ' as stationary phase, the effect of nature of surfactants (anionic, cationic or nonionic) and the level of concentration of each surfactant [sodium dodecyl sulfate (SDS), N-cetyl-N, $\mathrm{N}, \mathrm{N}$-trimethylammonium bromide (CTAB) or t- octyl phenoxydacaethoxy ethanol (TX-100)] on the mobility of all four active components was examined. In addition, the effect of organic (urea and alkanols) and inorganic $(\mathrm{NaCl})$ additives in 5\% aqueous SDS solution on mobility pattern of active herbal pharma ingredients was examined. The presence of ammonia and nitrate in the drug sample was found to hamper the resolution and identification of all active components. However, $\mathrm{NaCl}, \mathrm{KCl}$ and glucose do not offer serious interference.
\end{abstract}

Key Words: Thin layer chromatography, herbal, jatiphaladya, ayurvedic, surfactant.

\section{INTRODUCTION}

Jatiphaladya is a powdered herbal formulation of 6000 year old Indian ayurvedic system of medicine. Therapeutically Jatiphaladya is beneficial in many human intestinal disorders like tastelessness (aruci), Diarrhea (Atisara), Malabsorption syndrome (Graha), Dysentery (Pravahika), Cough (Kasa) and Rhinitis (Vatsale-ma-Pratisyaya). The main constituents of Jatiphaladya formulation are Cannabis sativa (Bhang), Myristica fragrans (Jatiphala), Piper longum (Pippali) and Embleia ribes (Vidanga) [1]. Cannabis sativa (Bhang) is a major constituent of the Jatiphaladya formulation $(20 \% \mathrm{wt} / \mathrm{vol})$. It is a commonly grown herb of high medicinal importance [2]. Myristica fragrans (Jatiphala) commonly known as nutmeg, is a popular herbal plant used in traditional Ayurvedic, Chinese and Thai medicine as aphrodisiac, antimicrobial, antipyretic, abortifacient and stomachic [3]. This plant is pharmacologically studied for various activities like chemo protective,

*Address correspondence to this author at the Analytical Research Laboratory, Department of Applied Chemistry, Faculty of Engineering \& Technology, Aligarh Muslim University, Aligarh-202002, India;

E-mail: alimohammad08@gmail.com antioxidant, aphrodisiac, antimicrobial, hepatoprotective, and anti-inflammatory [4]. Piper longum (Pippali) is a widely available species of the genus piper. Because of high therapeutic values, pipali has been used as antibacterial, anti-inflammatory and as a local anesthetic [5]. Embleia ribes (Vidanga) is a climbing herb found in Sri-lanka, India and Singapore. Therapeutically Embeleia inhibited pregnancy, possessed anti-estrogenic and weak progestational activity, shows analgesic, anti-inflammatory, antibacterial, antitumor and free radical scavenging activities $[6,7]$. As per our literature survey there is no analytical study available for Jatiphaladya formulation, But Previously Cannabis was analysed by various analytical methods including immunoassays (EMIT, Elisa fluorescence polarization, radioimmunoassay) [8], Gas Chromatography- Mass spectrometry [9], High performance liquid chromatographyMass spectrometry [10] and TLC [11]. However in case of Myristica fragrans (Jatiphal), Piper longum (Pippali) and Embleia ribes (Vidanga) a very few analytical studies are available using GC or HPLC [12-14]. Most of these techniques involves costly instruments and require highly purified standard reference samples [15]. Thin Layer Chromatography is a suitable method to screen simultaneously numerous samples extracted directly from 
plants. It has become a modern technique with the commercialization of numerous adsorbents and solvent systems [16].

Micellar liquid chromatography involving the use of surfactant ions above their critical micellar concentration (CMC) as mobile phase for controlling the retention of a solute has been the focus of numerous studies [17-19]. The use of surfactants (cationic, anionic, and nonionic) in TLC has expanded its potentiality by providing efficient separations of peptides [20], vitamins [21], steroids [22] etc. Surfactant-modified TLC provides enhanced selectivity as a result of difference in the degree of binding of separated mixture components with mobile and stationary phases [23]. The selective solubilization of mixture components with micelles is caused by complex electrostatic, hydrophobic, donor-acceptor and polarization interactions. Micelles are capable by differentially solubilizing and binding a variety of solutes leading to their potential usefulness for achieving several new separations including the resolution of optical isomers [24]. The present communication is probably the first report on the use surfactant in TLC analysis of an herbal formulation (Jatiphaladya).

\section{MATERIALS AND METHODOLOGY}

\section{Apparatus}

A TLC applicator (Toshiwal, India) was used for coating silica gel on $20 \mathrm{~cm} \times 3 \mathrm{~cm}$ glass plate. A glass sprayer and iodine gas chamber was used to locate the position of spot of analyte. A pH meter (Elico, India) and a reflux assembly of Borosil India were also used.

\section{Chemicals and Reagents}

Silica Gel 'G', sodium dodecyl sulfate (SDS), N-cetyl-N, $\mathrm{N}$, N-trimethylammonium bromide (CTAB), t- octyl phenoxydacaethoxy ethanol (TX-100), methanol, propanol, butanol and buffer capsules for $\mathrm{pH} 2.4,4.0$ and 9.2 (on dilution with $100 \mathrm{~mL}$ distilled water) were obtained from Merck Reagents, Mumbai, India. Sulfuric acid, iodine, vanillin and ethanol were from $\mathrm{CDH}$ India, Jatiphaldaya formulation was from Baidyanath Pharmaceutical Ltd India.

Parent API herbs, Cannabis sativa (Bhanga), Myristica fragrans (Jatiphala), Piper longum (Pippali) and Embleia ribes (Vidanga) were obtained from Ashyuwani herbal Pharmaceuticals, U.P., India.

\section{Chromatography}

\section{Mobile Phases}

The following solvent systems (Table 1) were used for the chromatography.

Stationary phase: Silica gel G was used as a stationary phase.

\section{Detection Reagent}
(a) Iodine vapors
(b) $1 \%$ solution of vanillin in methanolic sulfuric acid.
(c) Sulfuric-acid anisaldehyde solution.

Table 1. Solvent Systems

\begin{tabular}{|c|c|}
\hline Code & Constituents \\
\hline $\mathrm{M}_{1}$ & Water \\
\hline $\mathrm{M}_{2}$ & $0.5 \%$ aqueous $\mathrm{CTAB}$ \\
\hline $\mathrm{M}_{3}$ & $1 \%$ aqueous $\mathrm{CTAB}$ \\
\hline $\mathrm{M}_{4}$ & $2 \%$ aqueous $\mathrm{CTAB}$ \\
\hline $\mathrm{M}_{5}$ & $4 \%$ aqueous $\mathrm{CTAB}$ \\
\hline $\mathrm{M}_{6}$ & $5 \%$ aqueous $\mathrm{CTAB}$ \\
\hline $\mathbf{M}_{7}$ & $7 \%$ aqueous $\mathrm{CTAB}$ \\
\hline $\mathrm{M}_{8}$ & $0.5 \%$ aqueous SDS \\
\hline $\mathrm{M}_{9}$ & $1 \%$ aqueous SDS \\
\hline $\mathrm{M}_{10}$ & $2 \%$ aqueous SDS \\
\hline $\mathbf{M}_{11}$ & $4 \%$ aqueous SDS \\
\hline $\mathrm{M}_{12}$ & $5 \%$ aqueous SDS \\
\hline $\mathrm{M}_{13}$ & $7 \%$ aqueous SDS \\
\hline $\mathbf{M}_{14}$ & $0.5 \%$ aqueous $\mathrm{TX}-100$ \\
\hline $\mathrm{M}_{15}$ & $1 \%$ aqueous TX-100 \\
\hline $\mathrm{M}_{16}$ & $2 \%$ aqueous TX-100 \\
\hline $\mathrm{M}_{17}$ & $4 \%$ aqueous TX-100 \\
\hline $\mathrm{M}_{18}$ & $5 \%$ aqueous TX-100 \\
\hline $\mathrm{M}_{19}$ & $7 \%$ aqueous TX-100 \\
\hline $\mathrm{M}_{20}$ & $5 \%$ aqueous SDS + Methanol $(9: 1)$ \\
\hline $\mathrm{M}_{21}$ & $5 \%$ aqueous SDS + Methanol $(8: 2)$ \\
\hline $\mathrm{M}_{22}$ & $5 \%$ aqueous SDS + Methanol $(7: 3)$ \\
\hline $\mathrm{M}_{23}$ & $5 \%$ aqueous SDS + Methanol $(6: 4)$ \\
\hline $\mathrm{M}_{24}$ & $5 \%$ aqueous SDS + Methanol $(5: 5)$ \\
\hline $\mathbf{M}_{25}$ & $5 \%$ aqueous SDS + Methanol $(4: 6)$ \\
\hline $\mathrm{M}_{26}$ & $5 \%$ aqueous SDS + Ethanol $(8: 2)$ \\
\hline $\mathrm{M}_{27}$ & $5 \%$ aqueous SDS + Ethanol $(5: 5)$ \\
\hline $\mathrm{M}_{28}$ & $5 \%$ aqueous SDS + Ethanol $(2: 8)$ \\
\hline $\mathrm{M}_{29}$ & $5 \%$ aqueous SDS + Propanol $(8: 2)$ \\
\hline $\mathrm{M}_{30}$ & $5 \%$ aqueous SDS + Propanol $(5: 5)$ \\
\hline $\mathrm{M}_{31}$ & $5 \%$ aqueous SDS + Propanol $(2: 8)$ \\
\hline $\mathrm{M}_{32}$ & $5 \%$ aqueous SDS + Butanol $(8: 2)$ \\
\hline $\mathrm{M}_{33}$ & $5 \%$ aqueous SDS + Butanol $(5: 5)$ \\
\hline $\mathrm{M}_{34}$ & $5 \%$ aqueous SDS + Butanol $(2: 8)$ \\
\hline $\mathrm{M}_{35}$ & $5 \%$ aqueous SDS containing $1 \mathrm{~g} \mathrm{NaCl}$ per $100 \mathrm{~mL}$ \\
\hline $\mathrm{M}_{36}$ & $5 \%$ aqueous SDS containing $5 \mathrm{~g} \mathrm{NaCl}$ per $100 \mathrm{~mL}$ \\
\hline $\mathrm{M}_{37}$ & $5 \%$ aqueous SDS containing $1 \mathrm{~g}$ Urea per $100 \mathrm{~mL}$ \\
\hline $\mathrm{M}_{38}$ & $5 \%$ aqueous SDS containing $5 \mathrm{~g}$ Urea per $100 \mathrm{~mL}$ \\
\hline $\mathrm{M}_{39}$ & $5 \%$ aqueous SDS in buffer solution of $\mathrm{pH} 2.3$ \\
\hline $\mathrm{M}_{40}$ & $5 \%$ aqueous SDS in buffer solution of $\mathrm{pH} 4.2$ \\
\hline $\mathrm{M}_{41}$ & $5 \%$ aqueous SDS in buffer solution of $\mathrm{pH} 5.7$ \\
\hline $\mathrm{M}_{42}$ & $5 \%$ aqueous SDS in buffer solution of $\mathrm{pH} 9.1$ \\
\hline
\end{tabular}




\section{Extraction of Drug}

A powdered sample of herb was dried at $65{ }^{\circ} \mathrm{C}$ for 17 hours. A weighed amount of material ( $5 \mathrm{gm}$ herb powder) was added to $20 \mathrm{ml}$ of ethanol: water $(8: 2)$ solution and allowed to stand at room temperature for four hr. After that solution was refluxed on water bath for $30 \mathrm{~min}$, cooled and then filtered through a small funnel plugged with cotton wool and Watman filter paper (41). The solid residue obtained was again washed with $10 \mathrm{ml}$ of Ethanol: water (4:1) solution. After that all filtrates and washings were collected and solvent was evaporated. The final residue obtained after drying was further dissolved in $10 \mathrm{ml}$ of toluene containing $0.5 \mathrm{mg} / \mathrm{mL}$ of drug as standard [25].

\section{Preparation of TLC Plates}

The TLC plates were prepared by mixing silica gel $G$ with double distilled water in 1:3 ratios by weight with constant shaking to obtain homogeneous slurry. The resultant slurry was applied on the glass plates with the help of a manual TLC applicator to give a $0.25 \mathrm{~mm}$-thick layer. The plates were dried at room temperature and then activated at $100 \pm 2{ }^{\circ} \mathrm{C}$ by heating in an electrically controlled oven for one $\mathrm{hr}$. The activated plates were stored in a close chamber at room temperature until used.

\section{Chromatographic Procedure}

Test solutions $(10 \mu \mathrm{L})$ were applied on $(15 \times 3 \mathrm{~cm})$ silica gel $\mathrm{G}$ thin layer plates with the help of micropipette at about $2 \mathrm{~cm}$ above the lower edge of the plates. The solvent ascent was fixed to $10 \mathrm{~cm}$ in all cases for the determination of $R_{F}$ values of all individual drugs. Linear ascending development was carried out in a vapor equilibrated TLC twin trough chamber. The optimized chamber saturation time for the mobile phase was $15 \mathrm{~min}$ at room temperature $\left(25 \pm 1{ }^{0} \mathrm{C}\right)$. Subsequent to the development, TLC plates were dried at room temperature. The spot were then detected and compared by using iodine vapors, vanillin sulfuric acid and sulfuric acid aniseldhyde solution as chromogenic reagents and all the drugs are visualized as colored spots. For comparing spot intensity, $10 \mu \mathrm{L}$ aliquot $(0.5 \mathrm{mg} / \mathrm{mL})$ were loaded on silica gel TLC plate and chromatography was performed with different mobile phases $\left(\mathrm{M}_{1}-\mathrm{M}_{42}\right)$ and then spots were visualized using a common detector. The identified spots were visually compared for spot intensity. The $R_{F}$ values of drug were determined by the following relation -

$$
\mathrm{R}_{\mathrm{F}}=0.5\left(\mathrm{R}_{\mathrm{L}}+\mathrm{R}_{\mathrm{T}}\right)
$$

Where $\mathrm{R}_{\mathrm{L}}=\mathrm{R}_{\mathrm{F}}$ of leading front.

$$
\mathrm{R}_{\mathrm{T}}=\mathrm{R}_{\mathrm{F}} \text { of trailing front. }
$$

\section{Separation}

For the separation, equal amount of solution of drugs to be separated were mixed and $10 \mu \mathrm{L}$ of the resultant mixture was loaded on the TLC plates. The plates were developed with solvent system $\left(\mathrm{M}_{12}\right)$ and the spots were detected and the $R_{F}$ values of the separated drugs were determined. For separation of active constituents from Jatiphaladya formulation drug was extracted from the formulation and $10 \mu \mathrm{L}$ of this extract was loaded on TLC plates and chromatography was performed.

\section{Effect of Different Modifiers in Solvent System}

To study the effect of change in microenvironment of solvent systems due to presence of alkanols, $\mathrm{pH}$ buffers, electrolytes $(\mathrm{NaCl})$ and non electrolyte (urea) on the identification and mobility of all the four herbal drugs, different alcohols (methanol, ethanol, propanol and butanol) and 5\% aqueous SDS solution prepared in $1 \%$ and $5 \%$ aqueous solution of $\mathrm{NaCl}$ and urea were used as solvent systems. After that the chromatography was performed on silica gel layers with these solvent systems $\left(\mathrm{M}_{20^{-}}-\mathrm{M}_{42}\right)$ and $\mathrm{R}_{\mathrm{F}}$ values are calculated and compared

\section{Interference}

For investigating the interference of various organic and inorganic metabolites like sodium and potassium salts, urea, liquor ammonia, nitrate and glucose as an sample impurity, on the identification and mobility of herbal drugs (Bhanga, Jataiphala, Pippali and Vidanga), an aliquot (10 $\mathrm{L}$ ) of all herbal drugs were spotted separately on silica gel TLC plate followed by spotting of $10 \mu \mathrm{L}$ of the interfering species $(1 \mathrm{mg} / \mathrm{mL})$ on the same spot. The chromatography was performed with solvent system $\mathrm{M}_{12}$. The spots were detected and the $R_{F}$ values of drugs were calculated and compared.

\section{Detection Limits with Different Detectors}

The detection limits of jatiphala, bhanga, pippali and vidanga were determined by spotting different amounts of all the four compounds on silica gel stationary phase, developed with solvent system $\left(\mathrm{M}_{12}\right)$ and the spots were detected with various detectors such as -

(a) Iodine vapors

(b) $1 \%$ solution of vanillin in methanolic sulfuric acid

(c) Sulfuric acid anisaldhyde.

The method was repeated with successive lowering of the amount of drugs. The lowest amount that could be detected was taken as the limit of detection for each detector.

\section{RESULTS}

The four main constituents (Bhanga, Jatiphala, Pippali and Vidanga) of an aurvedic herbal formulation Jatiphaladya have been separated by using micellar thin layer chromatatography. These four constituents of Jatiphaladya were first extracted from their natural sources using aqueous organic solvent and then chromtographed on silica gel layers with various surfactant mediated solvent systems $\left(\mathrm{M}_{2}-\mathrm{M}_{19}\right)$. The surfactants used in this study differ mainly on the basis of the charge present on their hydrophilic groups. The results of the present study are reported in Table 2 . In addition to the effect of nature of charge of various surfactants, the additive effect of various organic and inorganic modifiers, electrolytes and non-electrolytes, as well as the $\mathrm{pH}$ of the solvent system were utilized to examine the chromatographic behavior of these herbal drugs.

The following conclusions are drawn from the results reported in Table $\mathbf{2}$ for the effect of nature of different surfactants on the chromatography of these herbal drugs. 
Table 2. $\quad \mathbf{R}_{\mathrm{F}}$ values (mobility) of Cannabis sativa (Bhanga), Embleia ribes (Vidanga), Myristica fragrans (Jathiphala) and Piper longum (Pippali) on Silica Gel 'G' Layers with Different $\left(\mathrm{M}_{1}-\mathrm{M}_{42}\right)$ Mobile Phases

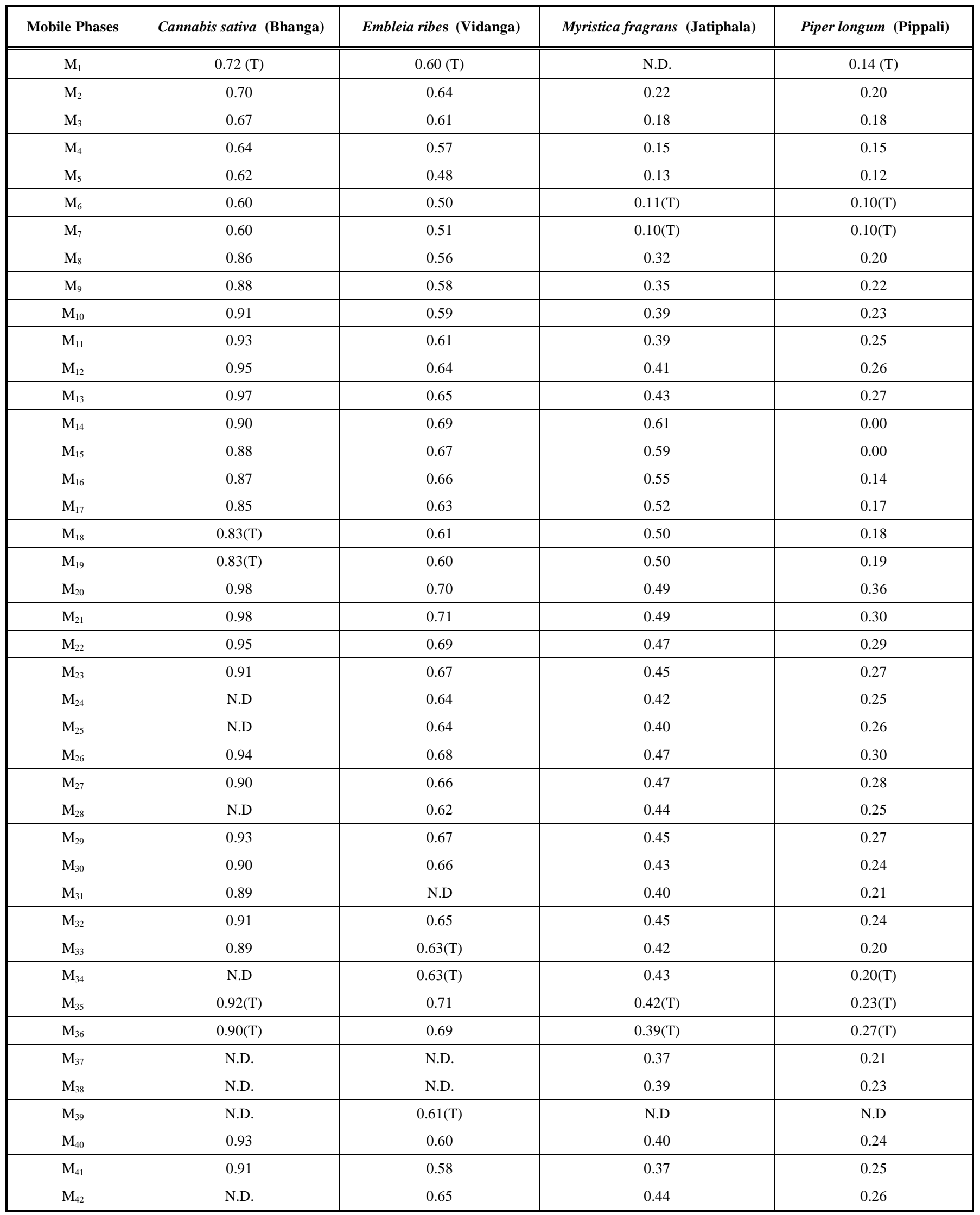


(1) In double distilled water (zero concentration of surfactants), Jatiphala was not detected while the other compounds appeared as tailed spots with different mobility.

(2) In case of CTAB and TX-100, the mobility of Bhanga, Vidanga and Jatiphala decreases with the increase in concentration of surfactant in the solvent system while in case of Pippali mobility increases with the increase in concentration of TX-100 in solvent system and decreases in case of CTAB.

(3) The SDS containing solvent systems have shown appreciable increase in the mobility of all the four herbal drugs with the increase in the concentration of surfactant in the solvent system.

\section{Effect of Alkanols}

The results of the additive effects of various organic modifiers such as alcohols in the micellar mobile phase $\mathbf{M}_{12}$ on the mobility of all the four drugs studied are presented in Table 2. It is clear from the results that the presence of traces of alcohols in solvent system increases the mobility of all the four drugs but further increase in concentration of various alcohols viz. methanol, ethanol, propanol and butanol in the micellar mobile phase $\left(\mathrm{M}_{12}\right)$ decreases the mobility of all the four drugs.

\section{Effect of Electrolyte and Non Electrolyte}

It has been reported [26] that the microenvironment of micellar system is greatly influenced by the presence of added organic substance or inorganic electrolytes. Thus the effect of addition of urea (organic non electrolyte) and $\mathrm{NaCl}$ (inorganic electrolyte) at two different concentration levels in the solvent system $\mathrm{M}_{12}(5 \%$ SDS) on mobility of all the four herbal drugs were examined. The results presented in Table 2 shows following noticable trend -

(1) In urea containing solvent systems $\left(\mathrm{M}_{37^{-}} \mathrm{M}_{38}\right)$ both Bhanga and Vidanga are not detected while in case of Pippali and Jatiphala the mobility decreases.

(2) In case of $\mathrm{NaCl}$ containing solvent systems $\left(\mathrm{M}_{35}-\mathrm{M}_{36}\right)$, all the three drugs (Jatiphala, Pippali and Bhanga) produced tailed spots except Vidanga.

\section{Effect of pH}

The results showing effect of $\mathrm{pH}(2.3,4.2,5.7$ and 9.0) of the solvent systems $\left(\mathrm{M}_{39}-\mathrm{M}_{42}\right)$ on the mobility of all the four herbal drugs are presented in Table 2. It is clear from the results that in strongly acidic $\mathrm{pH}$ none of the drugs except Vidanga was detected on TLC plates. In the $\mathrm{pH}$ range $4.2-$ 5.7 no significant change in mobility was observed for all drugs. At pH 9.1 Bhanga could not be detected.

\section{Limits of Detection}

The lowest possible amount of all the drugs detected using various detection reagents on silica gel surfaces with solvent system $\mathbf{M}_{12}$ are presented in Table $\mathbf{3}$. The results obtained indicate that vanillin sulfuric acid is most suitable for sensitive and efficient detection of drugs under study.

\section{Interference Studies}

It is clear from Table $\mathbf{4}$ that the presence of various organic and inorganic metabolites like sodium and potassium salts, urea, liquor ammonia, nitrate and glucose in the herbal

Table 3. Limit of Detection $(\mu \mathrm{g} / \mathrm{mL})$ Achieved Using Different Detection Reagents on Silica Gel 'G' Layers with Solvent System $M_{12}$

\begin{tabular}{|c|c|c|c|}
\hline \multirow{2}{*}{ Herbal Drug } & \multicolumn{3}{|c|}{ Detection Reagents } \\
\cline { 2 - 4 } & Iodine & Vanillin Sulfuric Acid & Sulfuric Acid Anisaldehyde \\
\hline \hline Embleia ribes & $0.20 \mu \mathrm{g} / \mathrm{mL}$ (light brown) & $0.50 \mu \mathrm{g} / \mathrm{mL}$ (bluish grey) & $0.90 \mu \mathrm{g} / \mathrm{mL}(\mathrm{blue})$ \\
\hline Myristica fragrans & $0.40 \mu \mathrm{g} / \mathrm{mL}$ (brown) & $0.20 \mu \mathrm{g} / \mathrm{mL}$ (light pink) & $0.70 \mu \mathrm{g} / \mathrm{mL}($ orange) \\
\hline Piper longum & $0.70 \mu \mathrm{g} / \mathrm{mL}$ (brown) & $0.30 \mu \mathrm{g} / \mathrm{mL}$ (light yellow) & $1.0 \mu \mathrm{g} / \mathrm{mL}(\mathrm{green})$ \\
\hline Cannabis sativa & $0.90 \mu \mathrm{g} / \mathrm{mL}$ (black brown) & $0.40 \mu \mathrm{g} / \mathrm{mL}$ (violet) & $0.80 \mu \mathrm{g} / \mathrm{mL}(\mathrm{black})$ \\
\hline
\end{tabular}

Table4. Effect of Various Organic and Inorganic Impurities (interference) on the Identification and Mobility ( $\mathbf{R}_{\mathrm{F}}$ ) of Cannabis sativa, Embleia ribes, Myristica fragrans and Pipper longum on Silica Gel 'G' Layers Developed with Solvent System $\mathrm{M}_{12}$

\begin{tabular}{|c|c|c|c|c|}
\hline Impurity & Cannabis sativa & Embleia ribes & Myristica fragrana & Pipper longum \\
\hline $\mathrm{NaCl}$ & $0.91 \mathrm{~T}$ & $0.58 \mathrm{~T}$ & $0.44 \mathrm{~T}$ & $0.32 \mathrm{~T}$ \\
\hline Urea & ND & 0.71 & 0.41 & ND \\
\hline Ammonia & ND & N.D. & 0.00 & $0.13 \mathrm{~T}$ \\
\hline Glucose & $0.94 \mathrm{~T}$ & $0.38 \mathrm{~T}$ & $0.47 \mathrm{~T}$ & ND \\
\hline
\end{tabular}


drug sample as impurities influences the mobility of all the four herbal drugs. In case of $\mathrm{NaCl}, \mathrm{KCl}$ and glucose as an interfering species all the three drugs produced tailed spots except Pippali which was not detected in glucose. Only Bhanga was detected when $\mathrm{N}_{\mathrm{O} 3}{ }^{-}$was used as an interfering species. No spot was detected for Bhanga and Vidanga in presence of ammonia. In case urea as an interfering species Bhanga and Pippali were not detected.

\section{DISCUSSION AND CONCLUSION}

It may be concluded from the results that in case of CTAB and TX-100, all the four drugs (Jatiphala, Pippali, Vidanga and Bhanga) are expelled or excluded from the micelle due to some sort of repulsion. This repulsion causes the increase in the retention of these compounds with the stationary phase with the increase in concentration of surfactants in the solvent system. While in case of SDS all the four drugs associate or bind with the micelle. This association with drugs causes a decrease in the retention of all the four drugs with stationary phase. This may also be concluded that these drugs behave as binding solutes for the SDS and the antibinding solutes for both CTAB and TX-100. From the chromatographic point of view, solvent system $\left(\mathrm{M}_{12}\right)$ was found to be best solvent system for the resolution of all the four herbal drugs due to higher $\Delta \mathrm{R}_{\mathrm{F}}$ values $\left[\left(\mathrm{R}_{\mathrm{F} \text { Bhanga }}-\right.\right.$ $\left.\mathrm{R}_{\mathrm{F} \text { Vidanga }}\right)$ and ( $\left.\left.\mathrm{R}_{\mathrm{F} \text { Jatiphala }}-\mathrm{R}_{\mathrm{F} \text { Pippali }}\right)\right]$ which was 0.31 and 0.15 respectively in solvent system $\mathrm{M}_{12}$ as compared to $\mathrm{M}_{20}(\Delta \mathrm{RF}$ values, 0.28 and 0.13 respectively) and also all the four drugs studied produced compact spots with high color intensity in 5\% aqueous SDS containing solvent system $\left(\mathrm{M}_{12}\right)$. Therefore, solvent system $\mathrm{M}_{12}$ is selected for the further study.

The mobility $\left(\mathrm{R}_{\mathrm{F}}\right)$ of all the four drugs is greatly affected by the presence of alcohols in the miceller solvent system. The addition of alcohols in the micellar solvent systems may result in the less population of surfactants molecules on the adsorbent and this may provide some free silanol groups on the silica surface for the adsorption of analyte [27] and also the addition of short-chain alcohols to the micellar mobile phase increases the polarity of solvent system and reduces the thickness of the film of surfactant molecules covering the stationary phase which results in increase of mobility of drugs. It is also reported that the addition of short-chain alcohols at lower concentrations also affects the micelle formation [28, 29]. From all the alcohols used butanol containing solvent system $\left(\mathrm{M}_{32}\right)$ provides highly compact spots for all the four drugs. This may be due to decrease in the polarity of the solvent system which in turn improves the efficiency and this could be related to improvement brought about by wetting the stationary phase with organic modifier. The actual polarity decreases in the order methanol> ethanol>propanol>butanol and hence efficiency follows the reverse trend as butanol<propanol<ethanol < methanol.

To widen the applicability of developed thin layer chromatographic method in the field of herbal drugs all the four constituents was identified and separated from ayurvedic formulation Jatiphaladya. Simultaneous use of other sensitive analytical methods such as HPLC and GC-MS may further provide the evidence about accuracy of our developed TLC system and data for estimation of biochemical structural composition of these herbals for future research. All the four important herbal drugs were identified and separated from an ayurvedic herbal formulation Jatiphaladya. The identification and resolution of Cannabis sativa (Bhanga), Embleia ribes (Vidanga), Myristica fragrans (Jatiphala) and Piper longum (Pippali) from Jatiphaladya ayurvedic formulation on silica gel layers with solvent system $M_{12}$ is shown in Fig. (1). The characterization and comparative studies of these identified and separated herbals with their standards may be more informative and useful for the proposed chromatographic system during future analytical studies of these herbals drugs.

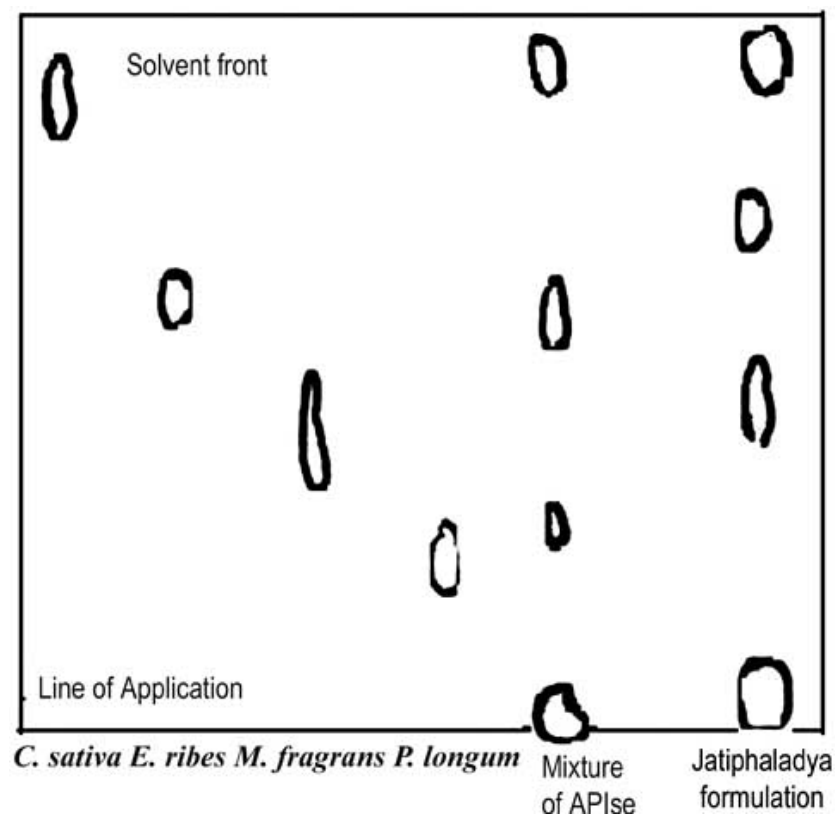

Fig. (1). Identification and Resolution of Cannabis sativa, E. ribes, $M$. fragrans and P. longum on Silica Gel Layers Developed with Solvent System M12.

\section{ACKNOWLEDGEMENT}

The authors are thankful to the Chairman, Department of Applied Chemistry, for providing research facilities to perform the work. Two of the authors (S. Sharma and S.A. Bhawani) are grateful to the University Grants Commission, New Delhi, for the financial assistance in the form of research fellowship.

\section{REFRENCES}

[1] The Ayurvedic pharmacopoeia of India, Part $2^{\text {nd }}$, Formulations. $1^{\text {st }}$ ed. Ministry of health and family welfare, Govt of India, 2008.

[2] Kumar RN, Chambers WA, Pertweer RG. Pharmacological actions and therapeutic uses of cannabis and cannabinoids. Anaesthesia 2001; 56: 1059-68.

[3] Nadkarni KM. Indian Materia Medica. 3rd ed. Bombay Popular Prakashan Mumbai 1994.

[4] Grover JK, Khandkar S, Vats V, Dhunno Y, Das D. Pharmacological studies on myristca fragrans antidiarrheal, hypnotic, analgesic and hemodynamic (blood pressure) parameters. Exp Clin Pharmacol 2002; 24: 675-81.

[5] Parthasarthy U, Asish GR, Saji KV, et al. Spatial influence on the important volatile oils of piper nigrum leaves. Curr Sci 2008; 94: 1632-35.

[6] Patel RP, Shah CS, Khanna PN, Gandhi TP. Pharmacognostic and pharmacological studies of Embelia ribes burm f. and Embelia 
tsjeriam-cottam $\{\mathrm{A}\}\{\mathrm{DC}\}$ (syn $\{\mathrm{E}\}$. robusta Clarke). Indian $\mathrm{J}$ Pharm 1964; 26: 168-72.

[7] Elizabeth MW. Major herbs of Ayurveda. Elsevier Health Sci. ed. illustrated 2002.

[8] Fraser AD, Worth D. Monitoring urinary excretion of cannabinoids by fluorescence - polarization immunoassay: a cannabinoid-tocreatinine ratio study. Ther Drug Monit 2002; 24: 746-50.

[9] Teske J, Putzbach K, Engewald W, Müller RK. Determination of cannabinoids by gas chromatography-mass spectrometry and large-volume programmed-temperature vaporiser injection using $25 \mu \mathrm{l}$ of biological fluid. J Chromatogr B Anal Technol Biomed Life Sci 2002; 772: 299-06.

[10] Weinmann W, Vogt S, Goerke R, Muller C, Bromberger A. Simultaneous determination of THC-COOH and THC-COOHglucuronide in urine samples by LC/MS/MS. Forensic Sci Int 2000; 113: 381-87.

[11] Debruyne D, Albessard F, Bigot MC, Moulin M. Comparison of three advanced chromatographic techniques for Cannabis identification. Forensic Sci Int 1999; 106: 135- 46.

[12] Beyer J, Dorothea E, Maurer HH. Abuse of nutmeg (Myristica fragrans houtt.): Studies on the metabolism and the toxicologic detection of its ingredients elemicin, myristicin, and safrole in rat and human urine using gas chromatography/ mass spectrometry. Ther Drug Monit 2006; 28: 568-75.

[13] Jain SC, Manghani E, Jain R. Fluroescence and HPLC based standrization of Piper nigrum fruits. Int J Botany 2007; 14: 208-13.

[14] Sudhakar RS, Unnikrishnan KP, Ravindran PN, Balchandran I. Determination of embelin in Embelia ribes and Embelia tsjeriamcottam by HPLC. Indian J Pharm Sci 2005; 67: 734-6.

[15] Leo ML. Handbook of Food Analysis: Physical characterization and nutrient analysis. $2^{\text {nd }}$ ed. CRC Press 2004.

[16] Sherma J, Fried B. Handbook of thin-layer chromatography. $3^{\text {rd }}$ ed. CRC Press 2003.

[17] Shtykov SN. Surfactant in analysis: Progress and development trends. J Anal Chem 2008; 55 (7): 608-14.
[18] Shtykov SN, Sumina EG, Smushikina EV, Tyurina NV. Dynamic and static modification of stationary phases with surfactants in TLC: A comparative study. J Planar Chromatogr 2000; 13 (3): 1829.

[19] Savvin SB, Chernova RK, Shtykov SS. Poverkhnostno-aktivnye veshchestva (surfactants). $1^{\text {st }}$ ed. Moscow Press: Nauka 1991.

[20] Cserhati T, Forgacs E, Deyl Z, Miksik I, Eckhardt A. Interaction of surfactants with homologous series of peptides studied by reversedphase thin - layer chromatography. J Chromatogr A 2001; 910(1): 137-45.

[21] Kartsova LA, Koroleva OA. Simulataneous determination of water and fat soluble vitamins by high-performance thin layer chromatography using an aqueous micellar mobile phase. J Anal Chem 2007; 62(3): 255-9.

[22] Kartsova LA, Strel nikova EG. Separation of exogeneous and endogenoussteroid harmones by micellar high performance thin layer chromatography. Anal Chem 2007; 62 (9): 872-4.

[23] Mohammad A, Zehra A. Surfactant modified silica phase for sorption of essential amino acids by thin layer chromatography. Colloids Surf A 2007; 301: 404-11.

[24] Hassan Aboul-Enein Y. Sepration techniques in clinical chemistry. CRC Press 2003.

[25] Narayanaswami K, Golani HC, Bami HL, Dua RD. Stability of Cannabis sativa L. samples and their extracts, on prolonged storage in Delhi. Bull Narcot 1978; 30: 321-32.

[26] Borgerding MF, Hinze WL. Characterization and evaluation of the use of nonionic polyoxyethylene dodecanol micellar mobile phases in reverse phase HPLC. Anal Chem 1985; 57: 2183- 90.

[27] Dorsey JG, Etchegaray De MT, Landy JS. Cetylpyridinium chloride (DDPC), as micellar mobile phase modifiers. Anal Chem 1983; 55: 924- 8.

[28] Hinze WL. Organized media in chemical separations. $2^{\text {nd }}$ ed. American chemical society press: Washington D.C. 1987.

[29] Magid L. Solution chemistry of surfactants. $4^{\text {th }}$ ed. Platinum press: New York 1979.

(c) Mohammad et al.; Licensee Bentham Open.

This is an open access article licensed under the terms of the Creative Commons Attribution Non-Commercial License (http://creativecommons.org/licenses/by-nc/3.0/) which permits unrestricted, non-commercial use, distribution and reproduction in any medium, provided the work is properly cited. 